\title{
Tribute to Dr Luis Fernando Bicudo Pereira Costa Rosa (GG)
}

\section{Estela Maris Andrade Forell Bevilacqua and José Roberto Machado Cunha da Silva*}

\author{
Laboratório de Histofisiologia Evolutiva, Departamento de Biologia Celular e do Desenvolvimento, \\ Instituto de Ciências Biomédicas, Universidade de São Paulo, Av. Prof. Lineu Prestes, \\ 1524, sala 409, CEP:05508-900, São Paulo, SP, Brazil
}

We have been asked to pay our respects on behalf of the Department of Cell and Developmental Biology to our dear colleague Luis Fernando Bicudo Pereira Costa Rosa, who tragically passed away on May 19, 2005, at the age of 40, after he met with an accident while cycling. We have to confess we have had a hard time coming up with the words. We hope we have achieved the right blend of respect and admiration to adequately memorialize him in these short few lines of ink.

Luis Fernando (known to his friends as GG) was born in São Paulo, Brazil, on December 31, 1964, as the oldest child of Antonio Fernando and Maria Cecília. He graduated from the University of São Paulo (USP), where he majored in Biology. He received his master's degree and $\mathrm{PhD}$ under the supervision of Professor Rui Curi in 1992 and in 1995, respectively, at the USP. He started his academic career in the Department of Physiology and Biophysics, Institute of Biomedical Sciences, at the USP before moving to the Department of Cell and Developmental Biology in 1995, where he remained until he died. On December 21, 1990, he married Marília Seelaender, also our colleague at the Department of Cell and Developmental Biology. As he liked often to say, his children, Isabel and Felipe, were his most important accomplishments. Among the things that made Luis Fernando unique, and which all of those who knew him will miss, were his energy, his unquiet spirit and his sincere talking.

He was an exceptional athlete and had been rowing champion at the state level many times and the Brazilian university champion a couple of times, as well as competing in many athletic running events. He won numerous medals in cycling,

\footnotetext{
*For reprints and all correspondence: José Roberto Machado Cunha da Silva, Laboratório de Histofisiologia Evolutiva, Departamento de Biologia Celular e do Desenvolvimento, Instituto de Ciências Biomédicas, Universidade de São Paulo, Av. Prof. Lineu Prestes, 1524, sala 409, CEP:05508-900, São Paulo, SP, Brazil. Tel: +55-11-3091-7223; Fax: +55-11-3091-7402; E-mail: jrmcs@usp.br
}

running and triathlon competitions. All this energy was also reflected in his academic career. The force with which he fought for his ideals (scientific and political) and his indefatigable persuasion of others to consolidate research in the area of exercise physiology were, without a doubt, meritorious. As part of a group of specialists he coordinated an annual specialization course, one of only a few in this area of expertise in Brazil. Luis Fernando was widely known for his research and professional contributions on exercise metabolism and immune function. He authored or coauthored 65 scientific papers on these subjects. As everyone who knew Luis Fernando will recognize, his scientific talk was not a purely cerebral affair but was always rich in emotion, excitement and nervous tension-something peculiar to those who share his love for his subject. As an advisor, his actions always were and still are a guide to the large group of graduate and undergraduate students and colleagues who had associations with him. His spirit also could be justly defined as that of a sportsman, for his fascination for sporting activities transcended his scientific activities. He was an inspiration to his students, and his influence, I am sure, will be felt by us for several decades. So it is with great sadness that I bid farewell to Luis Fernando on behalf of our colleagues. His family, colleagues and friends loved him dearly. He will be deeply missed by all of us.

As a faculty member of the Laboratory of Metabolism, Department of Histology and Embryology, Institute of Biomedical Sciences, USP, Brazil, Luis F. B. P. Costa Rosa was the author of one of our most accessed articles ("Exercise as a Time-conditioning Effector in Chronic Disease: A Complementary Treatment Strategy"), published in the first issue of $e C A M$.

The Editor-in-Chief was a personal friend of his, and on behalf of all the editorial staff and the board of $e C A M$, we extend our profound sympathy to his family and friends.

(C) The Author (2006). Published by Oxford University Press. All rights reserved.

The online version of this article has been published under an open access model. Users are entitled to use, reproduce, disseminate, or display the open access version of this article for non-commercial purposes provided that: the original authorship is properly and fully attributed; the Journal and Oxford University Press are attributed as the original place of publication with the correct citation details given; if an article is subsequently reproduced or disseminated not in its entirety but only in part or as a derivative work this must be clearly indicated. For commercial re-use, please contact journals.permissions@oxfordjournals.org 


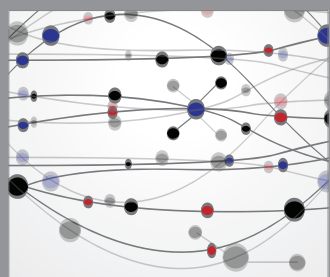

The Scientific World Journal
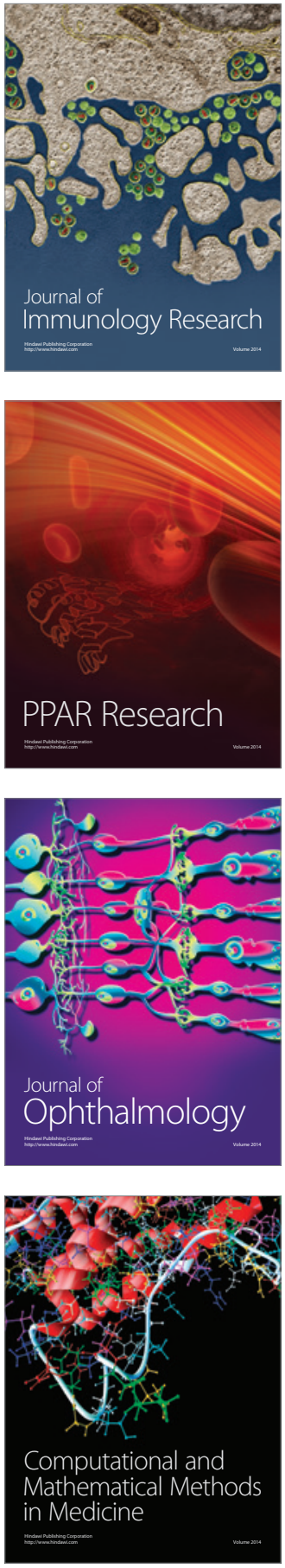

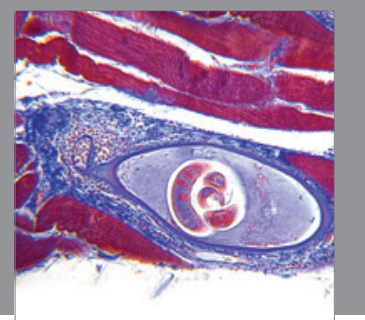

Gastroenterology

Research and Practice
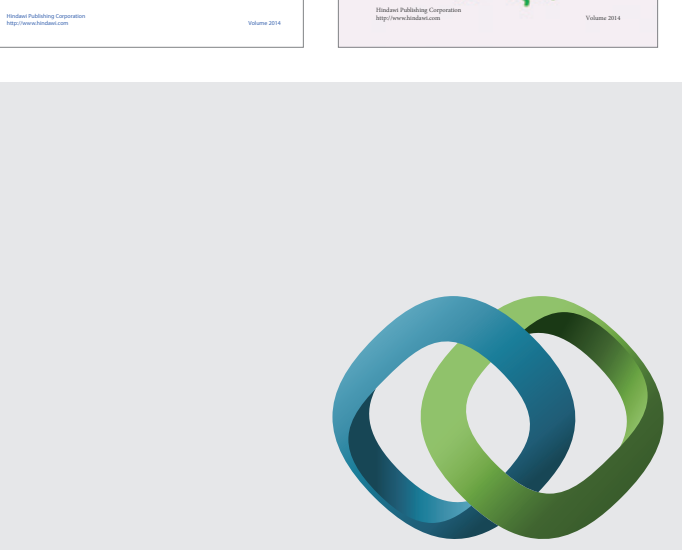

\section{Hindawi}

Submit your manuscripts at

http://www.hindawi.com
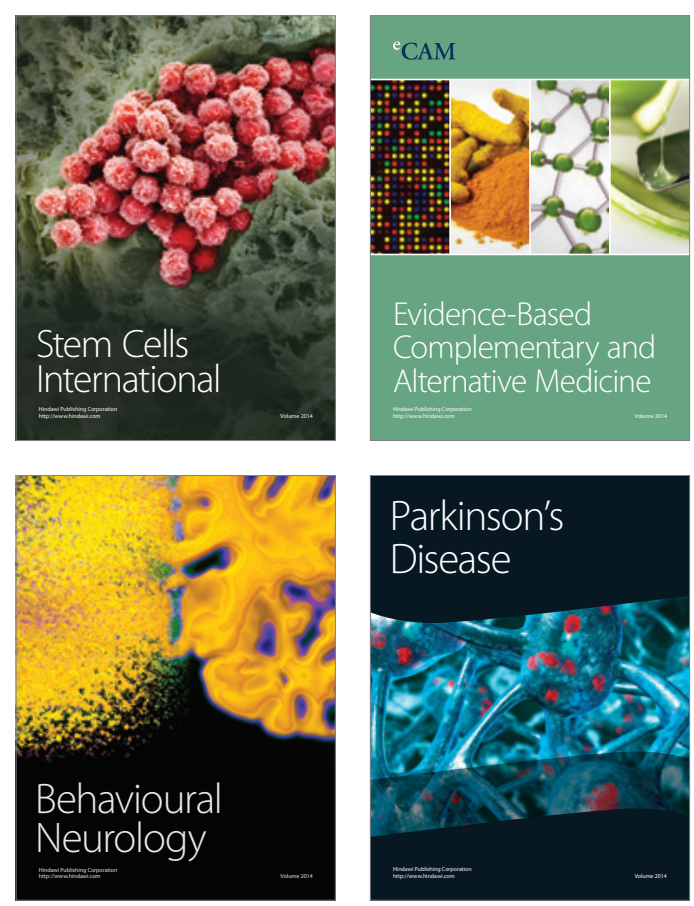

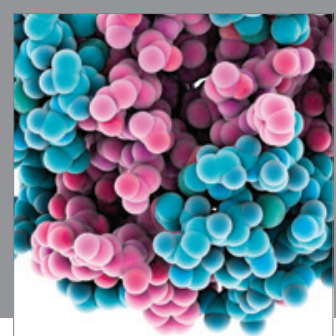

Journal of
Diabetes Research

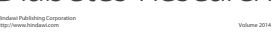

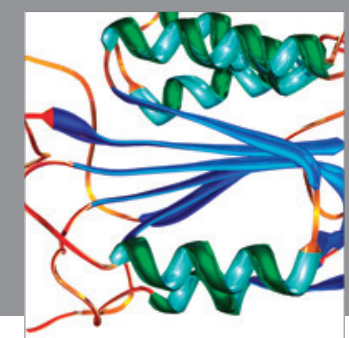

Disease Markers
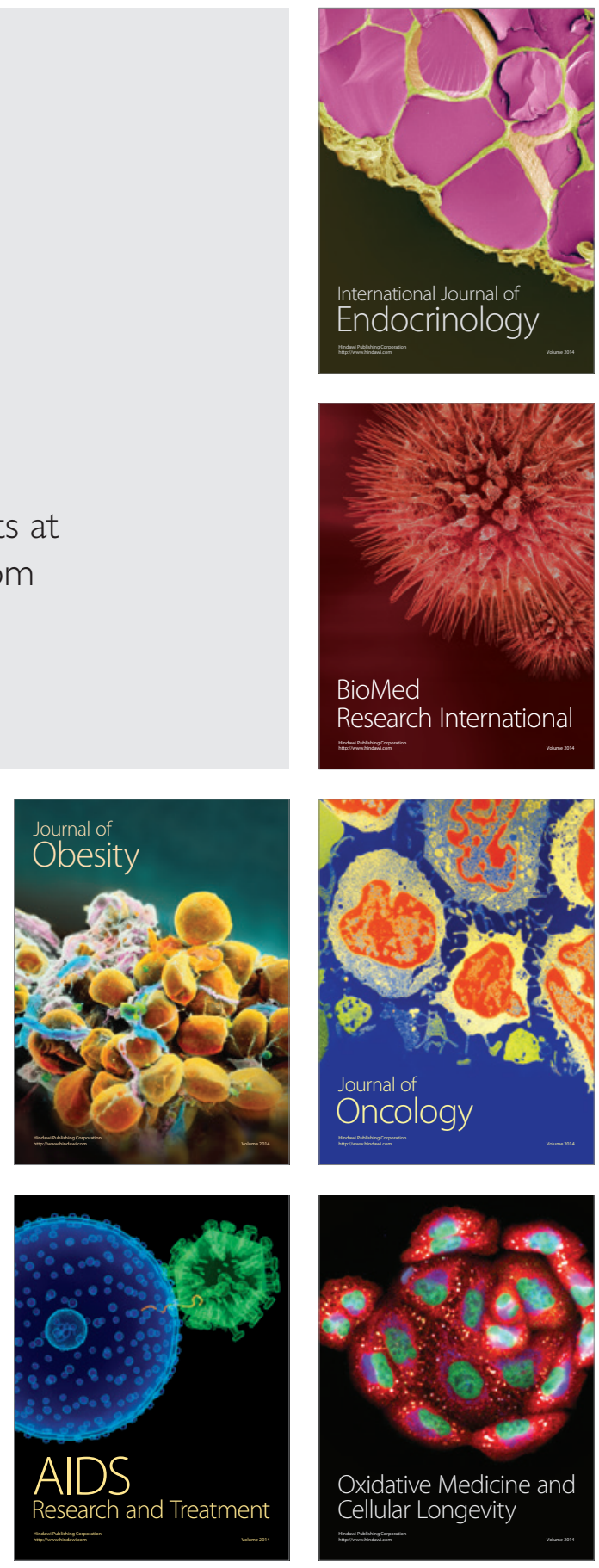